\begin{tabular}{|c|l|}
\hline Title & New evidence for the involvement of prostagl andin receptor EP4b in ovul ation of the medaka, Oryzias latipes. \\
\hline Author(s) & Fujimori, Chika; Ogiwara, Katsueki; Hagiwara, A kane; Takahashi, Takay uki \\
\hline Citation & $\begin{array}{l}\text { Molecular and cellular endocrinology, 362(1-2), 76-84 } \\
\text { https://doi.org/10.1016/.mce.2012.05.013 }\end{array}$ \\
\hline Issue Date & 2012-10-15 \\
\hline Doc URL & http://hdl.handle.net/2115/49982 \\
\hline Type & article (author version) \\
\hline File Information & articles.pdf \\
\hline
\end{tabular}

Instructions for use 


\section{New evidence for the involvement of prostaglandin receptor EP4b in ovulation of the medaka, Oryzias latipes}

Chika Fujimori, Katsueki Ogiwara, Akane Hagiwara, Takayuki Takahashi*

Laboratory of Reproductive and Developmental Biology, Faculty of Science, Hokkaido University, Sapporo 060-0810, Japan

Supported in part by Grants-in-Aid for Scientific Research (no. 21370024 to T.T.) from the Ministry of Education, Culture, Sports, Science and Technology of Japan

${ }^{*}$ Corresponding author:

Takayuki Takahashi, Laboratory of Reproductive and Developmental Biology, Faculty of Science, Hokkaido University, Sapporo 060-0810, Japan. Fax: 81-11-706-4851; e-mail: ttakaha@sci.hokudai.ac.jp

Running title: A role for EP4b in medaka ovulation 


\begin{abstract}
A cDNA for a prostaglandin $\mathrm{E}_{2}\left(\mathrm{PGE}_{2}\right)$ receptor subtype 4 , EP4b (Ptger4b), was cloned from the medaka ovary. The effect of $\mathrm{PGE}_{2}$ was examined using COS-7 cells expressing the recombinant Ptger4b protein. An increase in intracellular cAMP levels was observed when the cells were incubated with $\mathrm{PGE}_{2}$, but the increase in cAMP levels was nullified by the addition of the EP4 antagonist GW627368X. The expression of ptger $4 b$ mRNA was drastically induced by the addition of pregnant mare serum gonadotropin to the in vitro culture of large preovulatory follicles. In in vitro ovulation studies of the effect of GW627368X addition on follicle ovulation, the critical timing of the $\mathrm{PGE}_{2} /$ Ptger $4 \mathrm{~b}$ interaction was suggested to be between -1 and $0 \mathrm{~h}$ of ovulation. These results further substantiate that $\mathrm{PGE}_{2} / \mathrm{Ptger} 4 \mathrm{~b}$ signaling is involved in follicle rupture during ovulation in the medaka ovary.
\end{abstract}




\section{Introduction}

Prostaglandins (PGs) act as mediators of various physiological processes including inflammation, the contraction of smooth muscle, platelet aggregation, thermoregulation, wound healing, water balance, glomerular filtration, and homeostasis (Simmons et al., 2004; Sirois et al., 2004 ; Sugimoto and Narumiya, 2007). The involvement of PGs in the female reproductive process is well documented. For instance, previous studies have demonstrated that $\mathrm{PGE}_{2}$, a dominant prostaglandin species in the ovary, plays an important role in mammalian ovulation (Espey and Richards, 2006). Additional studies in mice lacking the gene encoding the PG-producing enzyme cyclooxygenase-2 $(\mathrm{COX}-2)$ or the $\mathrm{PGE}_{2}$ receptor $\mathrm{EP} 2$ have further elucidated the role of $\mathrm{PGs}$ in the process of cumulus oocyte complex (COC) expansion during ovulation (Hizaki et al., 1999; Richards et al., 2002).

The involvement of PGs in the ovulatory process has also been reported for some teleosts and amphibians (Cetta and Goetz, 1982; Patino et al., 2003; Lister and Van Der Kraak, 2008, 2009; Schuetz, 1986; Chang et al., 1995, 1997; Ramos et al., 2008; Sena and Liu, 2008; Liu et al., 2010; Fujimori et al., 2011). These studies strongly suggest that PGs have a conserved role in ovulation in vertebrates, including teleost fish. However, it should be noted that there are clear differences in the tissue structures of ovarian follicles in mammalian and non-mammalian species. The large follicle in mammals consists of a round oocyte and two types of somatic cells, granulosa cells and theca cells. Some of the granulosa cells surround the oocyte and form the COC, which protrudes toward the interior of an antrum filled with follicular fluid. The remainder of the granulosa cells are positioned just below the basement membrane in multiple cell layers known as the membrane granulosa. Theca cells, which are present on the outside 
of the basement membrane, also exist in multiple cell layers with rich extracellular matrix (ECM) components. On the other hand, the large follicle of non-mammalian species (from Pisces to Aves) consists of a single layer of granulosa cells surrounding an oocyte, a single layer of theca cells, and a basement membrane between the two layers (Pendergrass and Schroeder, 1976; Iwamatsu and Ohta, 1989). A COC is not formed in the fully grown follicle of non-mammalian vertebrate ovaries. Therefore, the role of PGs in the expansion of the COC in preovulatory follicles of the mammalian ovary does not extend to non-mammalian vertebrate species. Despite a general understanding of the importance of PGs in the ovulatory process of non-mammalian vertebrates, at present, little is known about the nature of the role PGs play in this process.

Medaka, Oryzias latipes, is a small egg-laying freshwater teleost that has a short life span and a rapid onset of sexual maturation. This fish has proved to be a good model for ovulation studies of non-mammalian vertebrates. In vitro ovulation using the fish ovary (Ogiwara et al., 2010) or fully grown ovarian follicles (Schroeder and Pendergrass, 1976; Ogiwara et al., 2005) serves as a powerful experimental system. Taking advantage of the suitability of medaka for ovulation studies, we have initiated studies to understand the mechanism by which PGs induce ovulation in vivo and in vitro. Our recent work indicated that $\mathrm{PGE}_{2}$ is involved in ovulation in the fish and is produced in the large preovulatory follicle destined to under ovulation by the COX-2 (Ptgs2) enzyme (Fujimori et al., 2011). Our data also indicated that the $\mathrm{PGE}_{2}$ receptor EP4b (Ptger4b) might be responsible for binding the $\mathrm{PGE}_{2}$ ligand (Fujimori et al., 2011). Interestingly, unlike the variable Ptgs2 expression during ovulation that has been reported in many vertebrate species, we found that the medaka COX-2 gene (ptgs 2 ) is expressed in the ovary at a relatively constant level. In contrast, EP4b transcript 
(ptger $4 b)$ levels increased dramatically as ovulation proceeded. These findings suggest that Ptger4b, but not Ptgs2, may be a key regulator of $\mathrm{PGE}_{2}$ action during the ovulatory process in the medaka fish.

In this study, we investigated the role of the Ptger $4 b$ receptor during fish ovulation. Our results demonstrate that ptger $4 b$ mRNA is expressed in the follicle layer cells of the large follicle and that ptger $4 b$ expression in medaka can be induced by pregnant mare serum gonadotropin (PMSG). Our current study also reveals that $\mathrm{PGE}_{2}$ binding to Ptger $4 \mathrm{~b}$ at the time of ovulation is critical for $\mathrm{PGE}_{2}$ function during medaka ovulation.

\section{Materials and methods}

\subsection{Animals and tissues}

Adult female medaka $O$. latipes were used. To establish a 24-h spawning cycle in the fish, they were acclimated to the artificial reproductive conditions of a $10-\mathrm{h}$ dark/14-h light cycle at $27^{\circ} \mathrm{C}$, as described previously (Fujimori et al., 2011). For this study, the start of the 14-h light period was designated as ovulation hour 0 , which corresponds to the time of ovulation in vivo. The staging of ovarian follicles was performed as previously described (Fujimori et al., 2011). Ovaries, ovarian follicles, follicle layers, the oocytes of the follicles, and other tissues were isolated at the

indicated time points. All experiments were approved by the Institutional Animal Use and Care Committee at Hokkaido University.

\subsection{In vitro culture and ovulation of large follicles}

In vitro ovulation of large ovarian follicles was carried out as described previously (Fujimori et al., 2011). In brief, large ovarian follicles isolated from adult female 
medaka ovaries were placed in a $1.9 \mathrm{~cm}^{2}$ tissue culture dish containing $1 \mathrm{ml} 90 \%$ medium 199 solution (Earle's medium 199; Dainippon-Sumitomo Seiyaku, Osaka, Japan) adjusted to $\mathrm{pH} 7.4$ with $\mathrm{NaHCO}_{3}$ and supplemented with $50 \mu \mathrm{g} / \mathrm{ml}$ gentamycin. The follicles were incubated at $26-27^{\circ} \mathrm{C}$. Approximately 10 follicles were cultured in each dish. The number of oocytes that were successfully ovulated was determined $6 \mathrm{~h}$ after the expected time of ovulation. The ovulation rate was defined as the percentage of ovulated follicles.

\subsection{Preparation of oocyte and follicle layer fractions from large follicles}

In the preovulatory follicles of medaka, the tight association between the follicle cell layers and the oocyte is diminished approximately $12 \mathrm{~h}$ before ovulation or later. During this time, we prepared the follicle cell layer and oocyte fractions from the follicles. Using preovulatory follicles isolated from ovaries 3,7 , and $11 \mathrm{~h}$ before ovulation, follicle cell layer and oocyte fractions were obtained. After washing with phosphate-buffered saline (PBS) three times, total RNA was extracted from each of the two fractions. RNA purity was assessed by RT-PCR analysis for membrane-type matrix metalloproteinase 2 ( $m m p 15)$, a marker gene of granulosa cells (Ogiwara et al., 2005), and collagen type I $\alpha 1$-chain (collal), a marker gene of theca cells (Horiguchi et al., 2008), using primers specific for the transcripts (Table 1). A specific band was amplified from the follicle layer RNA but not from the oocyte RNA, confirming that the oocyte fraction was not contaminated by theca cells or granulosa cells. The follicle cell layer and oocyte fractions were used for real-time RT-PCR analysis of ptger $4 b$ expression.

\subsection{Effect of EP4 antagonists on in vitro ovulation}


Large ovarian follicles were removed from the adult fish at 12,6 , or $3 \mathrm{~h}$ before the predicted time of ovulation and were incubated in culture medium with or without 10 $\mu$ M GW627368X, an EP4 antagonist (Cayman Chemicals, Ann Arbor, MI). For follicles isolated $3 \mathrm{~h}$ before ovulation, the antagonist, which was dissolved in DMSO, was added to the culture medium at time points ranging from $1 \mathrm{~h}$ to $3 \mathrm{~h}$ before ovulation. As a control, the follicles were also incubated in culture medium containing dimethyl sulfoxide (DMSO) alone. As a second control, the follicles were incubated without additives.

\section{5. $R N A$ isolation and reverse transcription $(R T)$-polymerase chain reaction $(P C R)$}

Total RNA was isolated from various medaka tissues, ovarian follicles, and cultured follicular cells using Isogen (Nippon Gene, Tokyo, Japan). Reverse transcription (RT) and PCR amplification were performed as previously described (Fujimori, et al., 2011). The primers used for RT-PCR are shown in Table 1.

\subsection{Cloning of medaka ptger $4 b c D N A$}

The gene-specific sense and antisense primers that were used for cloning were synthesized based on sequence data available from the Ensembl genome browser (http://www.ensembl.org/Oryzias_latipes/Info/Index). RT-PCR was conducted using KOD plus DNA polymerase (Toyobo, Osaka, Japan), total RNA prepared from medaka ovaries at $3 \mathrm{~h}$ before ovulation, and a combination of EP4bSS1 and EP4bAS1 primers (Table 1). The PCR reactions were cycled using the following parameters: $2 \mathrm{~min}$ at $94{ }^{\circ} \mathrm{C}, 30$ cycles of $15 \mathrm{~s}$ at $94{ }^{\circ} \mathrm{C}$ and $30 \mathrm{~s}$ at $60^{\circ} \mathrm{C}$, and $3 \mathrm{~min}$ at $68{ }^{\circ} \mathrm{C}$. RT-PCR resulted in the amplification of an 1854-bp ptger $4 b$ cDNA fragment. The amplified 
cDNA fragment was cloned into the pBluescript II KS(-) vector (Stratagene, La Jolla, CA) and sequenced.

The nucleotide sequence of the 5' upstream region (234 bp) of the ptger $4 b$ cDNA was obtained using the 5'-RACE method (Rapid Amplification of cDNA Ends) (Frohman et al., 1988) and the 5'-RACE system (Life Technologies, Rockville, MD) according to the manufacturer's protocol. The following primers were used: EP4bAS2 (for RT), EP4bAS3 (for the first PCR), and EP4bAS4 (for the second PCR) (Table 1). Two rounds of PCR reactions were performed. The first PCR conditions were as follows: $94{ }^{\circ} \mathrm{C}$ for $3 \mathrm{~min}, 35$ cycles of $30 \mathrm{~s}$ at $94{ }^{\circ} \mathrm{C}$ and $30 \mathrm{~s}$ at $55^{\circ} \mathrm{C}, 2 \mathrm{~min}$ at $72{ }^{\circ} \mathrm{C}$, and a final extension at $72{ }^{\circ} \mathrm{C}$ for $7 \mathrm{~min}$. The second PCR conditions were as follows: $94{ }^{\circ} \mathrm{C}$ for $3 \mathrm{~min}, 35$ cycles of $30 \mathrm{~s}$ at $94{ }^{\circ} \mathrm{C}$ and $30 \mathrm{~s}$ at $57^{\circ} \mathrm{C}, 2$ min at $72{ }^{\circ} \mathrm{C}$, and a final extension at $72{ }^{\circ} \mathrm{C}$ for $7 \mathrm{~min}$. The resulting 353-bp ptger $4 \mathrm{~b}$ fragment was subcloned into pBluescript II KS(-) vector for sequencing.

The 3' portion of medaka ptger4b was obtained using the 3'-RACE method (Frohman et al., 1988) and the 3'-full RACE Core Set (Takara, Tokyo, Japan) according to the manufacturer's protocol. The sense primers used were EP4bSS2 and EP4bSS3 (Table 1). Two rounds of PCR reactions were performed. The first PCR conditions were as follows: $94{ }^{\circ} \mathrm{C}$ for $3 \mathrm{~min}, 35$ cycles of $1 \mathrm{~min}$ at $94{ }^{\circ} \mathrm{C}$ and $1 \mathrm{~min}$ at $55{ }^{\circ} \mathrm{C}, 2 \mathrm{~min}$ at $72{ }^{\circ} \mathrm{C}$, and a final extension at $72{ }^{\circ} \mathrm{C}$ for $7 \mathrm{~min}$. The second PCR conditions were as follows: $94{ }^{\circ} \mathrm{C}$ for $3 \mathrm{~min}, 35$ cycles of $1 \mathrm{~min}$ at $94{ }^{\circ} \mathrm{C}$ and $1 \mathrm{~min}$ at $58^{\circ} \mathrm{C}, 2 \mathrm{~min}$ at $72{ }^{\circ} \mathrm{C}$, and a final extension at $72{ }^{\circ} \mathrm{C}$ for $7 \mathrm{~min}$. A 593-bp ptger $4 b$ fragment was obtained and sequenced.

To obtain a complete medaka ptger $4 b$ cDNA clone, RT-PCR was conducted using ovary RNA and EP4bSS4 and EP4bAS5 primers (Table 1). The PCR conditions were as 
follows: 2 min at $94{ }^{\circ} \mathrm{C}, 30$ cycles of $15 \mathrm{~s}$ at $94{ }^{\circ} \mathrm{C}$ and $30 \mathrm{~s}$ at $60^{\circ} \mathrm{C}$, and $3 \mathrm{~min}$ at $68^{\circ} \mathrm{C}$. The cDNA fragment was cloned as described above. A final ptger $4 b$ cDNA clone of 2404-bp was obtained and sequenced. A 2445-bp ptger $4 b$ sequence containing the above 2404-bp sequence was registered to the database as DDBJ/EMBL/GenBank Accession No. AB563504.

The sequencing reaction was performed using a BigDye Terminator Cycle Sequencing Kit v3.1 and was analyzed on an ABI PRISM 3100 Genetic Analyzer (Applied Biosystems, Foster City, CA).

2.7. Construction of ptger4b expression vectors and transfection of DNA into COS-7 cells

Full-length ptger4b was amplified using EP4bSS5 and EP4bAS6 primers and inserted into the pCMV-tag4 vector (Stratagene, La Jolla, CA). COS-7 cells were cultured in Dulbecco's modified Eagle medium (DMEM) containing 10\% fetal bovine serum (FBS) and 1\% penicillin-streptomycin-glutamine (Invitrogen, Carlsbad, CA). Transfection was performed using lipofectamine 2000 (Invitrogen) according to manufacturer's protocol. After $48 \mathrm{~h}$ of transfection, the COS-7 cells were used for cAMP assay.

\section{8. cAMP assay}

COS-7 cells transfected with ptger $4 b$ expression vectors were pretreated with $1 \mu \mathrm{M}$ indomethacin (INDO) (Sigma-Aldrich, St. Louis, MO) for $3 \mathrm{~h}$. The pretreated cells were

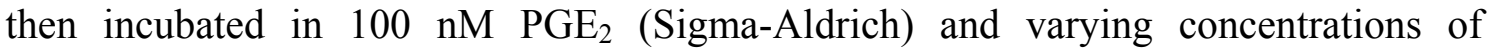
GW627368X at $37^{\circ} \mathrm{C}$ for 15 min. Levels of intracellular cAMP were measured using a 
cAMP-Glo assay Kit (Promega, Madison, WI).

\subsection{Real-time RT-PCR}

Preparation of total RNA, RT, and PCR reactions were performed as previously described (Fujimori et al., 2011). For real-time RT-PCR reactions, the threshold cycle $(\mathrm{Ct})$ is the cycle number at which the fluorescence generated within the reaction is significantly above background fluorescence. The RT-PCR primers used were EP4bSS6 and EP4bAS7. Dissociation curves were examined after each PCR run to ensure that a single PCR product had been amplified. PCR reactions were performed in triplicate on at least five separate RNA preparations from independent samples. To normalize ptger $4 b$ mRNA levels, we used the housekeeping genes cytoplasmic actin (actb), $18 S$ rRNA (rn18s1), or ribosomal protein L7 (rpl7) (Zhang and Hu, 2007).

For each experiment, RT-PCR was performed for each housekeeping gene, and the most stably expressed gene across all tissues examined was used to normalize ptger $4 b$ expression. Primer sequences for real-time RT-PCR are shown in Table 1 or were previously reported (Fujimori et al., 2011).

\subsection{Preovulatory follicle incubation with hormones}

Large ovarian follicles that were predicted to ovulate in the next spawning cycle were isolated from adult fish ovaries at $23 \mathrm{~h}$ before ovulation and incubated in the presence of the following hormones: $0.1 \mu \mathrm{M} 17 \alpha, 20 \beta$-dihydroxy-4-pregnen-3-one (17 $\alpha, 20 \beta$-DHP), $50 \mathrm{U} / \mathrm{ml}$ PMSG, or $50 \mathrm{U} / \mathrm{ml}$ human chorionic gonadotropin (hCG) (all hormones obtained from Sigma-Aldrich). Follicle viability after hormone treatment at $26-27^{\circ} \mathrm{C}$ for $20 \mathrm{~h}$ was assessed by trypan blue staining. Follicles incubated in the 
presence of the hormones were collected and subjected to total RNA extraction for real-time RT-PCR experiments. Follicles were collected every $4 \mathrm{~h}$ to examine the time-course of PMSG-induced ptger $4 b$ expression. For controls, the follicles were incubated in the culture medium without the addition of hormonal substances.

\subsection{Statistical analysis}

Data are presented as the mean values \pm SEM. of at least five independent experiments. Data were analyzed by ANOVA. For statistical evaluation, Tukey's post hoc test was used, and $P<0.05$ was considered significant.

\section{Results}

\subsection{Cloning and sequence analysis of a putative ptger $4 b$ cDNA clone}

Full-length medaka ptger $4 b$ cDNA was cloned (DDBJ/EMBL/GenBank Accession No. AB563504). The cDNA consists of a 248 bp 5'-untranslated region, an open reading frame of $1332 \mathrm{bp}$, and an $865 \mathrm{bp} \mathrm{3'-untranslated} \mathrm{region.} \mathrm{This} \mathrm{clone} \mathrm{encodes} \mathrm{a} \mathrm{protein} \mathrm{of}$ 443 amino acids (Fig. 1). The deduced amino acid sequences are 52.1\%, 50.9\% and $53.2 \%$ identical to human (Bastien et al., 1994), mouse (Honda et al., 1993), and zebrafish EP4 sequences (Cha et al., 2006), respectively. The protein sequence contains seven transmembrane domains typical of $\mathrm{G}$ protein-coupled receptors. Additionally, medaka EP4b contains conserved residues that are critical for stabilizing the structure and/or function of prostanoid receptors (Narumiya et al., 1999), including two cysteine residues (Cys-83 and Cys-161) for disulfide bond formation and three residues (Asp-56, Thr-159, Arg-284) that are involved in ligand binding. Two $N$-glycosylation sites (Asn-2 and Asn-169) were also present. Comparing our deduced sequence 
(DDBJ/EMBL/GenBank Accession No. AB563504) with the medaka Ptger4b sequence that is available from the draft medaka genome sequence database (http://www.ensembl.org/Oryzias_latipes/Info/Index) revealed the presence of a single amino acid residue substitution at Thr-139 (our sequence) for Ala (genome database sequence).

\subsection{Characterization of medaka Ptger $4 b$ in COS-7 cells}

COS-7 cells transfected with the pCMV-tag4 vector containing the medaka ptger $4 b$ cDNA were incubated with $100 \mathrm{nM} \mathrm{PGE}$. $\mathrm{PGE}_{2}$ treatment resulted in an increase in intracellular cAMP concentration by $120.9 \mathrm{nM}$ over that of untreated control cells (Fig. 2). The $\mathrm{PGE}_{2}$-induced cAMP elevation was abolished in the presence of the EP4 antagonist GW627368X at concentrations higher than $1 \mu \mathrm{M}$ antagonist.

\subsection{Expression of ptger $4 b \mathrm{mRNA}$ in medaka tissues}

Real-time RT-PCR assays were conducted using total RNA isolated from various medaka tissues (Fig. 3A). ptger4b mRNA was detected in all tissues examined; however, a relatively high expression of the gene was observed in the heart, kidney, spleen, and ovary. In the ovary, the highest expression of ptger $4 b$ mRNA was observed at $3 \mathrm{~h}$ before ovulation $(-3 \mathrm{~h})$. In contrast, ptger $4 b$ expression at $12 \mathrm{~h}$ before ovulation, an intermediate time point between ovulations, was low. Using real-time RT-PCR, we next determined the expression level of ptger $4 b$ in the spawning fish ovary on a 24-h spawning cycle. Levels of ptger $4 b$ mRNA remained low between $23 \mathrm{~h}$ and $11 \mathrm{~h}$ before ovulation; however, ptger $4 b$ expression levels rapidly increased as ovulation approached (Fig. 3B). 


\subsection{Ovarian expression of medaka ptger $4 b \mathrm{mRNA}$}

Small, medium, and large follicles were isolated separately from spawning medaka ovaries at 11 and $3 \mathrm{~h}$ before ovulation. Using real-time RT-PCR, the relative expression levels of ptger $4 b$ mRNA were determined (Fig. 4A). Large follicles isolated at -11 and $-3 \mathrm{~h}$ expressed higher levels of ptger $4 b \mathrm{mRNA}$ than small and medium follicles isolated at these time points. Further, the expression of ptger $4 b$ in large follicles isolated at $-3 \mathrm{~h}$ was approximately 4 times greater than in follicles isolated at $-11 \mathrm{~h}$. Next, we examined ptger $4 b$ expression using follicle layer and oocyte fractions prepared from preovulatory follicles at 3, 7, and $11 \mathrm{~h}$ before ovulation. As shown in Fig. 4B, ptger $4 b$ mRNA was almost exclusively expressed in the follicle layer of the preovulatory follicle at all time points examined. Finally, expression of other medaka EP receptors was examined by real-time RT-PCR using preovulatory follicles isolated at $3 \mathrm{~h}$ before ovulation. The expression levels of ptger $4 b$ mRNA were higher than any of the other ptger genes we examined. Setting the ptger $1 b$ expression level at 1 , the relative expression levels of ptgerla, ptger2, ptger3, ptger $4 a$, and ptger $4 b$ were higher than ptgerlb by 1.1-, 2.3-, 2.6-, 9.5-, and 330-fold, respectively.

\subsection{Effects of hormones on ptger $4 b$ mRNA expression}

To examine the effects of hormones on ptger $4 b$ mRNA expression, large preovulatory follicles were isolated at $-23 \mathrm{~h}$ and incubated in the presence of various hormones for $20 \mathrm{~h}$. Incubation with PMSG markedly increased ptger $4 b$ mRNA expression (Fig. 5A). Incubation with $0.1 \mu \mathrm{M} 17 \alpha, 20 \beta$-DHP had no effect on ptger $4 b$ mRNA expression. Treatment with hCG did not result in any significant increase in 
ptger $4 b$ mRNA expression. Interestingly, follicles cultured in vitro in the presence of PMSG grew as large as follicles observed in vivo, whereas follicles that were cultured in the presence of hCG did not grow at all. Follicles incubated in the presence of $17 \alpha$, 20ß-DHP grew slightly. All follicles were alive at the time of hormone treatment. Next, we assessed ptger $4 b$ mRNA expression across a time course in the PMSG-treated large follicles. The effect of PMSG became apparent $12 \mathrm{~h}$ after the start of incubation, at which point we began to observe a progressive increase in the levels of ptger $4 b$ mRNA as ovulation approached (Fig. 5B).

\subsection{Identification of the critical timing of the $P G E_{2} /$ Ptger4b interaction during normal} ovulation

To determine when Ptger $4 \mathrm{~b}$ activation by $\mathrm{PGE}_{2}$ occurs during medaka ovulation, large follicles isolated from spawning fish ovaries at various time points were incubated in the presence or absence of the EP4 antagonist GW627368X. Follicles isolated from ovaries at 12 or $6 \mathrm{~h}$ before the expected time of ovulation were incubated with GW627368X, resulting in few or no follicles achieving ovulation in vitro (Fig. 6). To determine the effect of the antagonist on in vitro ovulation, we examined follicles collected at $3 \mathrm{~h}$ before the expected ovulation time. Exposure of the follicles to the antagonist for $3 \mathrm{~h}(-3$ to $0 \mathrm{~h}), 2 \mathrm{~h}(-2$ to $0 \mathrm{~h})$ or $1 \mathrm{~h}(-1$ to $0 \mathrm{~h})$ immediately before ovulation resulted in strong suppression of the ovulation rate. In contrast, incubation of the follicles in the presence of the EP4 antagonist up to an hour before ovulation [2 h ( -3 to $-1 \mathrm{~h})$ or $1 \mathrm{~h}(-3$ to $-2 \mathrm{~h})$ ] did not affect the in vitro ovulation rate. This differential effect of GW627368X on follicle ovulation is most clearly observed in the follicles incubated with the antagonist for $1 \mathrm{~h}(-1$ to $0 \mathrm{~h})$ immediately prior to ovulation and in 
follicles treated for $2 \mathrm{~h}(-3$ to $-1 \mathrm{~h})$.

\section{Discussion}

Our previous studies have suggested that Ptger $4 \mathrm{~b}$, a prostaglandin $\mathrm{E}_{2}$ receptor subtype 4, plays an important role in mediating $\mathrm{PGE}_{2}$-induced ovulation in the medaka ovary (Fujimori et al., 2011). To substantiate this hypothesis, we initiated the present study by cloning the full-length ptger $4 b$ cDNA. The amino acid sequence of the cloned receptor was homologous to that found in other species and contained virtually all the conserved residues that are important for the structure and function of the receptor. Although the medaka Ptger $4 \mathrm{~b}$ amino acid sequence is only $51-53 \%$ homologous to the amino acid sequence of EP4 receptors from three other species (human, mouse, and zebrafish), the medaka receptor contains structural features that are similar to the zebrafish Ptger4. First, similar to zebrafish Ptger4, the $\mathrm{NH}_{2}$-terminal extracellular residue sequence of medaka Ptger $4 b$ is much shorter than that found in mammalian EP4s. Second, the medaka and zebrafish Ptger4 sequences contain a 24-26 residue deletion in the intracellular domain between MT5 and MT6 that is not found in mammalian EP4 sequences. Third, the $\mathrm{COOH}$-terminal intracellular domains of the medaka and zebrafish Ptger4 receptors are shorter by 14 residues and 47 residues, respectively, compared to their mammalian counterparts.

In the present study, we show that COS-7 cells expressing the putative medaka Ptger4b receptor exhibit increased intracellular cAMP levels when treated with $\mathrm{PGE}_{2}$. The PGE 2 -induced rise in cAMP levels was effectively suppressed by GW627368X. These results indicate that the putative medaka Ptger $4 \mathrm{~b}$ we identified is functional. Further, our results suggest that $\mathrm{PGE}_{2}$ may be a ligand of the medaka Ptger $4 \mathrm{~b}$ receptor, 
while GW627368X is a likely antagonist of the Ptger4b receptor. Consistent with this, we recently reported a drastic reduction in the in vitro ovulation rate of fish preovulatory follicles after treatment with GW627368X (Fujimori et al., 2011). Furthermore, we observed in the present study that preovulatory follicles nearing ovulation express high amounts of ptger $4 b$ mRNA relative to the other five medaka ptger genes. Based on these findings, we conclude that the antagonist functions to block $\mathrm{PGE}_{2}$ binding to the Ptger $4 \mathrm{~b}$ receptor and results in inhibition of in vitro follicle ovulation. However, it is formally possible that the interaction of GW627368X with other Ptger receptors may also contribute to a reduction in the overall follicle ovulation rate.

It is well documented that EP4 binds to PGs to activate a downstream intracellular cAMP-protein kinase signaling cascade in mammals (Regan, 2003; Sugimoto and Narumiya, 2007) and chickens (Kwok et al., 2008). Our finding that $\mathrm{PGE}_{2}$ treatment of medaka Ptger4b-expressing COS-7 cells results in the elevation of intracellular cAMP levels strongly suggests the operation of a similar intracellular signal transduction pathway in medaka. Future studies will help elucidate the molecular mechanism the $\mathrm{PGE}_{2} /$ Ptger4b interaction plays in follicle rupture during ovulation in medaka fish.

Expression of the ptger $4 b$ gene in the fish ovary varies considerably across the $24-\mathrm{h}$ spawning cycle. ptger $4 b$ mRNA levels are low at the intermediate stage between ovulations and high at the time of ovulation. We identified a 15 -fold difference in ptger $4 b$ transcript levels in the ovary between these two time points. The drastic increase in ptger $4 b$ transcripts in the preovulatory follicle during ovulation strongly suggests that the ptger $4 b$ gene is upregulated at the time of ovulation. Interestingly, we also found ptger $4 b$ to be upregulated in follicles treated in vitro with PMSG; however, 
from these studies, it is not clear how the gonadotropin acts to induce ptger $4 b$ expression. Specifically, does PMSG induce ptger $4 b$ expression in the follicle by a follicle stimulating hormone (FSH)-like action or a luteininzing hormone (LH)-like action? PMSG generally has FSH-like actions in mammalian species. However, PMSG has been reported to have a more broad effect on the ovarian follicles of medaka fish (Sakai et al., 1987), where it has been shown to increase estradiol production in vitellogenic follicles and induce oocyte maturation of post-vitellogenic follicles, possibly through its ability to generate $17 \alpha, 20 \beta$-DHP. Consistent with this, we have recently found in medaka that PMSG induces ovulation in post-vitellogenic follicles in our in vitro ovulation system (our unpublished data). The ovulation-inducing effect of PMSG in fish post-vitellogenic follicles in vitro has also been observed by Nagahama and Yamashita (2008). Thus, PMSG appears to have both FSH-like and LH-like actions in the follicles of the medaka fish. Previous studies revealed that LH receptor (Lhr) is expressed in the ovarian granulosa cells and theca cells that surround the oocyte in the preovulatory follicle in teleosts (Yaron et al., 2003; Rocha et al., 2007; Nagahama and Yamashita, 2008). These findings suggest that ptger $4 b$ gene expression in the follicle of the fish ovary could be mediated by an LH surge that involves the Lhr in vivo and that PMSG might mimic the action of LH in vitro. However, the involvement of FSH receptor (Fshr) in inducing ptger $4 b$ expression in the PMSG-treated follicle cannot be ruled out at present. To distinguish between these possibilities, further studies on the spatial and temporal expression of Fshr and Lhr in the preovulatory follicle, as well as studies addressing ligand specificity using recombinant medaka receptor proteins, are required. Because hCG is known to have LH-like activity in mammals, we tested whether the gonadotropin had any effect on the induction of ptger $4 b$ expression in 
follicles cultured in vitro. Unexpectedly, hCG had no effect on ptger $4 b$ expression. Future studies investigating ligand specificity of medaka gonadotropin receptors are needed to determine why PMSG, but not hCG, is capable of inducing ptger $4 b$ expression.

It is generally accepted that oocyte maturation in teleosts is mediated by the membrane progestin receptor, whereas ovulation is mediated by the nuclear progesterone receptor (Pgr) (Thomas and Das, 1997; Nagahama and Yamashita, 2008). The Pgr receptor associates with a specific progestin ligand and can also function as a transcription factor. The role of PGR in ovulation has been extensively studied in mammals (Natraj and Richards, 1993; Gava et al., 2004; Teilmann et al., 2006). In addition, a handful of studies on the function of Pgr in teleosts have also been published (Pinter and Thomas, 1995, 1999; Toda et al., 2000; Chen et al., 2010; Hanna et al., 2010). These studies show that teleost Pgr contains unique structural domains that exhibit homology to their mammalian counterparts and that, in zebrafish and Japanese eel, $17 \alpha, 20 \beta$-DHP is the most likely physiological ligand for the receptor. It has also been reported that this steroid hormone is a naturally occurring progestin in the medaka fish (Iwamatsu, 1978). Thus, we speculate that Pgr governs the expression of the ptger $4 b$ gene in medaka. If this is true, failure to induce ptger $4 b$ expression in preovulatory follicles with $17 \alpha, 20 \beta$-DHP alone may be due to a loss or low levels of Pgr in the follicles. We are now conducting studies to investigate a role for Pgr in the ovarian expression of the ptger $4 b$ gene in vivo.

In this study, we found that follicles cultured in vitro in the presence of PMSG for $16 \mathrm{~h}$ exhibited elevated expression of ptger $4 b$. Here, we should note that there is a difference in the timing of ptger $4 b$ expression between the in vitro PMSG-treated 
follicles and endogenous follicles receiving gonadotropin. Previous studies using hypophysectomized medaka suggest that, in adult female fish with an established 24-h spawning cycle, preovulatory follicles receive a surge of gonadotropic hormone, presumed to be Lh, between 21 and $15 \mathrm{~h}$ before the expected time of ovulation in vivo (Iwamatsu, 1978). In the fish, germinal vesicle breakdown (GVBD), a critical process for oocyte maturation, occurs approximately $6 \mathrm{~h}$ before ovulation in the follicle that is destined to ovulate in vivo (Iwamatsu, 1978). We previously reported that ptger $4 b$ mRNA levels increase $11 \mathrm{~h}$ before ovulation in vivo (Fujimori et al., 2011). These findings indicate that it takes $7 \mathrm{~h}$ from the time they undergo a surge of gonadotropin for the follicles to upregulate ptger $4 b$ expression in vivo. In our in vitro model, follicles isolated from the ovary $23 \mathrm{~h}$ before ovulation and several hours before the endogenous gonadotropin surge responded to PMSG treatment in a delayed manner. If we assume that PMSG binds to a putative gonadotropin receptor in the follicle approximately $18 \mathrm{~h}$ before ovulation, it takes approximately $11 \mathrm{~h}$ after the gonadotropin surge for the PMSG-treated follicles to upregulate ptger $4 b$ gene expression, indicating there is an approximately $4 \mathrm{~h}$ delay relative to the in vivo induction of ptger $4 \mathrm{~b}$. We also observed that GVBD and ovulation are delayed by approximately 2 and $3 \mathrm{~h}$, respectively, in the in vitro culture system when compared with the process occurring in vivo (our unpublished results). In spite of these delays in the timing of oocyte maturation and follicle ovulation in the PMSG-induced in vitro culture system, our in vitro experimental system has proved to be a helpful tool in investigating the involvement of the Ptger $4 \mathrm{~b}$ receptor in the ovulatory process in medaka.

The present study demonstrates that the Ptger4b antagonist GW627368X completely abolishes in vitro ovulation of large follicles even when added only $1 \mathrm{~h}$ before the time 
of ovulation. This result suggests that $\mathrm{PGE}_{2}$ functions to induce ovulation of large preovulatory follicles by binding to the EP4 receptor just before the time of ovulation. Further, this result suggests that $\mathrm{PGE}_{2} / \mathrm{Ptger} 4 \mathrm{~b}$ signaling is required for fish ovulation at the time that follicle rupture occurs. As has been previously reported (Ogiwara et al., 2005), the dissolution of the connective tissue matrix and collagen fibers in the follicle layers of ovulating follicles is essential for ovulation. Matrix metalloproteinase-2 (Mmp2, also known as gelatinase A) is activated by membrane type 1 matrix metalloproteinase (Mmp14) on the plasma membrane of the oocyte to hydrolyze collagen type IV, a major ECM component of the follicle basement membrane (Kato et al., 2010), and membrane type 2 matrix metalloproteinase (Mmp15) degrades collagen type I present in the theca cell layer (Horiguchi et al., 2008). Follicle rupture is effectively inhibited by the addition of metalloproteinase inhibitors, such as EDTA and GM6001, a few hours before the expected ovulation time (Ogiwara et al., 2005). Therefore, Mmp-catalyzed ECM degradation and $\mathrm{PGE}_{2}$ signaling events occurring at the apex of the follicle layer of the ovulating follicle are indispensable for successful ovulation in the fish. Importantly, these two distinct events proceed simultaneously during medaka ovulation.

In conclusion, we have cloned and characterized a cDNA clone from medaka ovaries that encodes Ptger $4 \mathrm{~b}$. When the fish ptger $4 b$ cDNA is expressed in COS-7 cells, the recombinant protein is functional and interacts with $\mathrm{PGE}_{2}$, resulting in an increase in intracellular cAMP levels. Expression of ptger $4 b$ in in vitro cultured large preovulatory follicles increases drastically following treatment with PMSG. This work also shows that the critical timing of $\mathrm{PGE}_{2}$ binding to the receptor occurs at or shortly before the time of ovulation. While a biological role for $\mathrm{PGE}_{2}$ in teleost ovulation has not yet been 
elucidated, we have established that $\mathrm{PGE}_{2} /$ Ptger $4 \mathrm{~b}$ signaling is critically involved in the process. To our knowledge, this is the first report of the expression and characterization of EP receptor genes in any teleost species and is the first to demonstrate a clear link between Ptger $4 \mathrm{~b}$ and ovulation in the medaka fish. Future studies will investigate the role of the prostaglandin in the ovulatory process in fish.

\section{Acknowledgments}

This study was supported by a Grant-in-Aid for Scientific Research for the Ministry of Education, Culture, Science, and Technology of Japan (21370024 to T.T.).

\section{References}

Bastien, L., Sawyer, N., Grygorczyk, R., Metters, K.M., Adam, M., 1994. Cloning, functional expression, and characterization of the human prostaglandin E2 receptor EP2 subtype. J. Biol. Chem. 269, 11873-11877.

Cetta, F., Goetz, F.W., 1982. Ovarian and plasma prostaglandin E and F levels in brook trout (Salvelinus fontinalis) during pituitary-induced ovulation. Biol. Reprod. 27, $1216-1221$.

Cha, Y.I., Kim, S.H., Sepich, D., Buchanan, F.G., Solnica-Krezel, L., DuBois, R.N., 2006. Cyclooxygenase-1-derived $\mathrm{PGE}_{2}$ promotes cell motility via the G-protein-coupled EP4 receptor during vertebrate gastrulation. Genes Dev. 20, 77-86.

Chang, K.J., Kim, J.W., Im, W.B., Kang, H.M., Kwon, H.B., 1997. Differential effects of gonagotropin and orthovanadate on oocyte maturation, ovulation, and prostaglandin synthesis by Rana ovarian follicles in vitro. J. Exp. Zool. 277, 
$155-165$

Chang, K.J., Kim, J.W., Lee, J., Im, W.B., Kwon, H.B., Scheutz, A.W., 1995. Prostaglandin production and ovulation during exposure of amphibian ovarian follicles to gonadotropin or phorbol ester in vitro. Gen. Comp. Endocrinol. 100, 257-266.

Chen, S.X., Bogerd, J., Garcia-Lopez, A., Jonge, H., Waal, P.P., Hong, W.S., Schulz, R.W., 2010. Molecular cloning and functional characterization of a zebrafish nuclear progesterone receptor. Biol. Reprod. 82, 171-181.

Espey, L.L., 1994. Current status of the hypothesis that mammalian ovulation is compatible to an inflammatory reaction. Biol. Reprod. 50, 233-238.

Espey, L.L., Richards, J.S., 2006. Ovulation. In: Neill, J.D. (eds.), Physiology of reproduction. Academic Press, Amsterdam, vol 1, 3rd edition, pp. 425-474.

Frohman, M.A., Dush, M.K., Martin, G.R., 1988. Rapid production of full-length cDNA from rare transcripts: amplification using a single gene-specific oligonucleotide primer. Proc. Natl. Acad. Sci. U.S.A .85, 8998-9002.

Fujimori, C., Ogiwara, K., Hagiwara, A., Rajapakse, S., Kimura, A., Takahashi, T., 2011. Expression of cyclooxygenase-2 and prostaglandin receptor EP4b mRNA in the ovary of the medaka fish, Oryzias latipes: possible involvement in ovulation. Mol. Cell. Endocrinol. 332, 67-77

Gava, N., Clarke, C., Byth, K., Amett-Mansfield, R., DeFazio, A., 2004. Expression of progesterone receptors $\mathrm{A}$ and $\mathrm{B}$ in the mouse ovary during the estrous cycle. Endocrinology 145, 3487-3494.

Hanna, R.H., Daly, S.C.J., Pang, Y., Anglade, I., Kah, O., Thomas, P., Zhu, Y., 2010. Characterization and expression of the nuclear progestin receptor in zebrafish 
gonads and brain. Biol. Reprod. 82, 112-122.

Hizaki, H., Segi, E., Sugimoto, Y., Hirose, M., Saji, T., Ushikubi, F., Matsuoka, T., Noda, Y., Tanaka, T., Yoshida, N., Narumiya, S., Ichikawa, A., 1999. Abortive expansion of the cumulus and impaired fertility in mice lacking the prostaglandin E receptor subtype $\mathrm{EP}_{2}$. Proc. Natl. Acad. Sci. U.S.A. 96, 10501-10506.

Honda, A., Sugimoto, Y., Namba, T., Watabe, A., Irie, A., Negishi, M., Narumiya, S., Ichikawa, A., 1993. Cloning and expression of a cDNA for mouse prostaglandin E receptor EP2 subtype. J. Biol. Chem. 268, 7759-7762

Horiguchi, M., Fujimori, C., Ogiwara, K., Moriyama, A., Takahashi, T., 2008. Collagen type-I $\alpha 1$ chain mRNA is expressed in the follicle cells of the medaka ovary. Zool. Sci. $25,937-945$

Ishikawa, T., Herschman, H.R., 2007. Two inducible, functional cyclooxygenase-2 genes are present in the rainbow trout genome. J. Cell. Biochem. 102, 1486-1492.

Iwamatsu, T., 1978. Studies on oocyte maturation of the medaka, Oryzias latipes. V. On the structure of steroids that induce maturation in vitro. J. Exp. Zool. 204, 401-408.

Iwamatsu, T., Ohta, T., 1989. Effects of forskolin on fine structure of medaka follicles. Dev. Growth Differ. 31, 45-53.

Iwamatsu, T., Ohta, T., Oshima, E., Sakai, N., 1988. Oogenesis in the medaka Oryzias latipes. Stage of oocyte development. Zool. Sci. 5, 353-373.

Kato, Y., Ogiwara, K., Fujimori, C., Kimura, A., Takahashi, T., 2010. Expression and localization of collagen type IV $\alpha 1$ chain in the medaka ovary. Cell Tissue Res. 340, 595-605.

Kasahara, M., Naruse, K., Sasaki, S., et al. 2007. The medaka draft genome and insights into vertebrate genome evolution. Nature 447, 714-719. 
Kwok, A.H., Wang, Y., Wang, C.Y., Leung, F.C., 2008. Molecular cloning and characterization of chicken prostaglandin E receptor subtypes 2 and 4 (EP2 and EP4). Gen. Comp. Endocrinol. 157, 99-106

Lister, A.L., Van Der Kraak, G., 2008. An investigation into the role of prostaglandins in zebrafish oocyte maturation and ovulation. Gen. Comp. Endocrinol. 159, 46-57.

Lister, A.L., Van Der Kraak, G., 2009.Regulation of prostaglandin synthesis in ovaries of sexually-mature zebrafish (Danio rerio). Mol. Reprod. Dev. 76, 1064-1075.

Liu, Z., Su, X., Li, T., Pan, D., Sena, J., Dhillon, J., 2010. Molecular cloning and expression of prostaglandin $\mathrm{F} 2 \alpha$ receptor isoforms during ovulation in the ovarian follicles of Xenopus laevis. Prostaglandins Other Lipid Mediat. 93, 93-99.

Nagahama,Y., Yamashita, M., 2008. Regulation of oocyte maturation in fish. Dev. Growth Differ. 50, S195-S219.

Nagahama, Y., Yoshikuni, M., Yamashita, M., Tanaka, M., 1994. Regulation of oocyte maturation in fish. In: Sherwood, N.M., Hew, C.L. (eds.), Fish Physiology. Academic Press, New York, pp. 393-439.

Narumiya, S., Sugimoto, Y., Ushikubi, F., 1999. Prostanoid receptors: structures, properties, and functions. Physiol. Rev. 79, 1193-1226.

Natraj, U., Richards, J., 1993. Hormonal regulation, localization, and functional activity of the progesterone receptor in granulosa cells of rat preovulatory follicles. Endocrinology 133, 761-769.

Ogiwara, K., Ikeda, T., Takahashi, T., 2010. A new in vitro ovulation model for medaka based on whole ovary culture. Zool. Sci. 27, 762-767.

Ogiwara, K., Takano, N., Shinohara, M., Murakami, M., Takahashi, T., 2005. Gelatinase A and membrane-type matrix metalloproteinases 1 and 2 are responsible for follicle 
rupture during ovulation in the medaka. Proc. Natl. Acad. Sci. U.S.A. 102, $8442-8447$.

Ozato, K., Wakamatsu, Y., 1994. Developmental genetics of medaka. Dev. Growth Differ. 36, 437-443.

Patino, R., Yoshizaki, G., Bolamba ,D., Thomas, P., 2003. Role of arachidonic acid and protein kinase $\mathrm{C}$ during maturation-inducing hormone-dependent meiotic resumption and ovulation in ovarian follicles of Atlantic croaker. Biol. Reprod. 68, 516-523.

Pendergrass, P.C., Schroeder, P., 1976. The ultrastructure of the thecal cell of the teleost, Oryzias latipes, during ovulation in vitro. J. Reprod. Fertil. 47, 229-233.

Pinter, J., Thomas, P., 1995. Characterization of a progestogen receptor in the ovary of the spotted seatrout, Cynoscion nebulosus. Biol. Reprod. 52, 667-675.

Pinter, J., Thomas, P., 1999. Induction of ovulation of mature oocytes by the maturation-inducing steroid 17, 20ß, 21-trihydroxy-4-pregnen-3-one in the spotted seatrout. Gen. Comp. Endorinol. 115, 200-209.

Ramos, I., Cisint, S.B., Crespo, C.A., Medina, M.F., Fernandez, S.N., 2008. Modulators of Bufo arenarum ovulation. Zygote 16, 65-72.

Regan, J.W., 2003. EP2 and EP4 prostanoid receptor signaling. Life Sci. 74, 143-153.

Richards, J.S., Russell, D.L., Ochsner, S., Espey, L.L., 2002. Ovulation: new dimensions and new regulators of the inflammatory-like response. Annu. Rev. Physiol. 64, 69-92.

Rocha, A., Gomez, A., Zanuy, S., Cerda-Reverter, J.M., Carrillo, M., 2007. Molecular characterization of two sea bass gonadotropin receptors: cDNA cloning, expression analysis, and functional activity. Mol. Cell. Endocrinol. 272, 63-76. 
Sakai, N., Iwamatsu, T., Yamauchi, K., Nagahama, Y., 1987. Development of the steroidogenic capacity of medaka (Oryzias latipes) ovarian follicles during vitellogenesis and oocyte maturation. Gen. Comp. Endocrinol. 66, 333-342.

Schroeder, P.C., Pendergrass, P., The inhibition of in-vitro ovulation from follicles of the teleost, Oryzias latipes, by cytochalasin B. J. Reprod. Fertil. 1976, 48, 327-30.

Schuetz, A.W., 1986. Hormonal dissociation of ovulation and maturation of oocytes: ovulation of immatureamphibian oocytes by prostaglandin. Gamete Res. 15, 99-113. Sena, J., Liu, Z., 2008. Expression of cyclooxygenase genes and production of prostaglandins during ovulation in the ovarian follicles of Xenopus laevis. Gen. Comp. Endocrinol. 157, 165-173.

Simmons, D.L., Botting, R.M., Timothy, H., 2004. Cyclooxygenase isozymes: The biology of prostaglandin synthesis and inhibition. Pharmacol. Rev. 56, 387-437.

Sirois, J., Sayasith, K., Brown, K.A., Stock, A.E., Bouchard, N., Dore, M., 2004. Cyclooxygenase-2 and its role in ovulation: a 2004 account. Hum. Reprod. Update. $10,373-385$.

Sugimoto, Y., Narumiya, S., 2007. Prostaglandin E receptors. J. Biol. Chem. 282, $11613-11617$.

Teilmann, S., Clement, C., Thorup, J., Byskov, A., Christensen, S., 2006. Expression and localization of the progesterone receptor in mouse and human reproductive organs. J. Endocrinol. 191, 525-535.

Thomas, P., Das, S., 1997. Correlation between binding affinities of C21 steroids for the maturation-inducing steroid membrane receptor in spotted seatrout ovaries and their agonist and antagonist activities in an oocyte maturation bioassay. Biol. Reprod. 57, 999-1007. 
Toda, T., Ikeuchi, T., Kobayashi, T., Kajiura-Kobayashi, H., Suzuki, K., Yoshikuni, M., Yamauchi, K., Nagahama, Y., 2000. Characterization of a testicular $17 \alpha$, 20ß-dihydroxy-4-pregnen-3-one (a spermiation-inducing steroid in fish) receptor from a teleost, Japanese eel (Anguilla japonica). FEBS Lett. 465, 12-17.

Wittbrodt, J., Shima, A., Schartl, M., 2002. Medaka--a model organism from the far East. Nat. Rev. Genet. 3, 53-64.

Yaron, Z., Gur, G., Melamed, P., Rosenfeld, H., Elizur, A., Levavi-Sivan, B., 2003. Regulation of fish gonadotropin. Int. Rev. Cytol. 225, 131-185.

Zhang, Z., and Hu, J., 2007. Development and validation of endogenous reference genes for expression profiling of medaka (oryzias latipes) exposed to endocrine disrupting chemicals by quantitative real-time RT-PCR. Toxicol. Sci. 95, 356-368.

\section{FIGURE LEGENDS}

Fig. 1. Amino acid sequence of medaka EP4b (Ptger4b) and comparison with EP4 
sequences from other vertebrate species.

Amino acid sequence alignment of medaka EP4b with human EP4 (NP_000949), mouse EP4 (NP_032990), and zebrafish EP4 (NP_001034718) sequences is shown. Residues identical among species are shaded in gray. Seven transmembrane (TM) domains are shown on the top. The two cysteine residues critical for disulfide bond formation are indicated by asterisks. Conserved residues that are critical for ligand binding (black triangles) and $N$-linked glycosylation sites (white triangles) are indicated.

Fig. 2. cAMP production in medaka Ptger4b-expressing COS-7 cells in response to $\mathrm{PGE}_{2}$.

COS-7 cells transfected with ptger $4 b$ expression vectors were incubated with $\mathrm{PGE}_{2}$ $(100 \mathrm{nM})$ and/or GW627368X $(0.1 \mu \mathrm{M}$ to $10 \mu \mathrm{M})$ at $37^{\circ} \mathrm{C}$ for $15 \mathrm{~min}$. Intracellular cAMP levels were determined as described in the Materials and Methods. The ordinate indicates the variation in concentrations compared to samples with no GW627368X treatment. Data are presented as the mean \pm S.E.M. $(n=5)$. Asterisks indicate significant differences at $P<0.05$ compared to the sample with $\mathrm{PGE}_{2}$ alone.

Fig. 3. Expression of ptger $4 b$ in medaka tissues.

(A) Real-time RT-PCR analysis was performed for ptger $4 b$ using total RNA isolated from various tissues of adult medaka fish. The ptger $4 b$ expression levels were normalized to levels of the medaka ribosomal protein L7 ( $r p l 7$ ) transcript. Relative ptger $4 b$ expression levels are expressed as the fold change in mRNA levels in ovaries that were isolated $11 \mathrm{~h}$ before ovulation $(-11 \mathrm{~h})$. Data are presented as the mean \pm S.E.M. $(\mathrm{n}=6)$. (B) Real-time RT-PCR analysis was conducted for ptger4b using total RNA 
isolated at the indicated time points from the ovaries of adult medaka with a $24 \mathrm{~h}$ spawning cycle. The expression levels of ptger $4 b$ were normalized to the levels of the cytoplasmic actin $(a c t b)$ transcript. Relative ptger $4 b$ expression levels are expressed as the fold change in mRNA levels in the $-23 \mathrm{~h}$ ovary. Data are presented as the mean \pm S.E.M. $(n=5)$.

Fig. 4. Expression of ptger $4 b$ in medaka preovulatory follicles.

(A) Real-time RT-PCR analysis of ptger $4 b$ transcripts using total RNA isolated from ovarian follicles of different sizes. Total RNA was isolated from small, medium and large follicles of fish ovaries at $11 \mathrm{~h}$ (white) and $3 \mathrm{~h}$ (black) before ovulation. The expression levels of ptger $4 b$ were normalized to those of $a c t b$ and are expressed as the fold change in mRNA levels in small follicles at $3 \mathrm{~h}$ before ovulation. Data are presented as the mean \pm S.E.M. $(\mathrm{n}=5)$. (B) Real-time RT-PCR analysis of ptger $4 b$ expression using total RNA isolated from oocytes and follicle layers of large follicles. Oocytes (white) and follicle layers (black) were prepared from large follicles isolated from spawning medaka at $11 \mathrm{~h}, 7 \mathrm{~h}$ and $3 \mathrm{~h}$ before ovulation, and the total RNA was extracted at each time point for the PCR analyses. The expression levels of ptger $4 b$ were normalized to medaka $18 S r R N A(r n 18 s 1)$ transcripts and are expressed as the fold change in the mRNA levels in the oocytes at $11 \mathrm{~h}$ before ovulation. Data are presented as the mean \pm S.E.M. $(n=5)$.

Fig. 5. Effects of hormones on ptger $4 b$ mRNA expression.

(A) Expression of ptger $4 b$ mRNA in large follicles incubated in the presence of $17 \alpha$, 20ß-DHP, PMSG, or hCG. The follicles were isolated from spawning medaka ovaries at 
$23 \mathrm{~h}$ before ovulation and were incubated with each of the hormones. After hormone treatment for $20 \mathrm{~h}$, total RNA was extracted from the treated follicles for real-time RT-PCR of ptger $4 b$ mRNA. As a control, total RNA was also extracted from follicles that were not treated with hormones. The expression levels of ptger $4 b$ mRNA were normalized to those of $a c t b$ and expressed as the fold change in the mRNA levels in the control follicles. Data are presented as the mean \pm S.E.M. $(n=5)$. (B) Expression of ptger $4 b$ mRNA in the presence or absence of PMSG. Large ovarian follicles were isolated at $23 \mathrm{~h}$ before ovulation and incubated in the presence of $50 \mathrm{U} / \mathrm{ml}$ PMSG. Total RNA was extracted from these follicles every $4 \mathrm{~h}$. Expression of ptger $4 b$ was estimated by real-time RT-PCR. The expression levels of ptger $4 b$ mRNA were normalized to those of the $a c t b$ transcript and expressed as the fold change in the mRNA levels in the zero-time control follicles. For each time point, the results for the control (left) and PMSG-treated follicles (right) are shown. Data are presented as the mean \pm S.E.M. $(n=5)$.

Fig. 6. Identification of the critical time point of the $\mathrm{PGE}_{2} / \mathrm{Ptger} 4 \mathrm{~b}$ interaction during normal follicle ovulation.

Large follicles (at least 10 follicles per experiment) were isolated from spawning fish ovaries at 12,6 , or $3 \mathrm{~h}$ before ovulation and incubated in the presence of the EP4 antagonist GW627368X (10 $\mu \mathrm{M})$ or DMSO (the solvent used to dissolve the antagonist). The timetable for follicle incubation with the antagonist or DMSO is indicated on the left. Gray bars indicate follicle incubation with the antagonist; white bars indicate incubation with the DMSO control. Control follicles incubated without additives are indicated by straight lines. The ovulation rates were determined at $6 \mathrm{~h}$ after ovulation, 
and the results are shown on the right. The mean value \pm S.E.M. of five independent experiments are shown. 
Table 1. PCR primers used in this study

\begin{tabular}{|c|c|c|c|}
\hline Primer name & Gene & Primer sequence & Accession No. /Ref. \\
\hline \multicolumn{4}{|c|}{ Cloning / 3'-RACE / 5'-RACE } \\
\hline EP4bSS1 & ptger $4 b$ & 5'-TCAGTGAGAAAAACGATGAATG-3' & AB563504 \\
\hline EP4bSS2 & ptger $4 b$ & 5'-GAGGATCTTCAGAAACCAGC-3' & \\
\hline EP4bSS3 & ptger $4 b$ & 5’-CTGTGAGAAGGTCTTCCTAG-3' & \\
\hline EP4bSS4 & ptger $4 b$ & 5’-AАACTTTCCTGTCTGC-3' & \\
\hline EP4bAS1 & ptger $4 b$ & 5’-ССАСССССТТАСАТСТGАТТ-3' & \\
\hline EP4bAS2 & ptger $4 b$ & 5’-CCAGGAGGTCCGTCACTG-3’ & \\
\hline EP4bAS3 & ptger $4 b$ & 5’-AAGTCGTCTCCTTCTGCTCTTTTC-3' & \\
\hline EP4bAS4 & ptger $4 b$ & 5'-TATCCGGAGAACCACGATGGCGAT-3' & \\
\hline EP4bAS5 & ptger $4 b$ & 5’-ACACATCACAGAACAACAG-3' & \\
\hline \multicolumn{4}{|c|}{ EP4b expression in COS-7 cells } \\
\hline EP4bSS5 & ptger $4 b$ & 5'-CCGGAATTCATGAATGAAACTCAG-3' & AB563504 \\
\hline EP4bAS6 & ptger $4 b$ & 5’-CCCAAGCTTAATGCATCTTTC-3' & \\
\hline \multicolumn{4}{|c|}{ Real-time RT-PCR } \\
\hline EP4bSS6 & ptger $4 b$ & 5’-CAGATGGTGATCCTGCTCAT-3' & AB563504 \\
\hline EP4bAS7 & ptger $4 b$ & 5'-GCCAGGAGGTCTTCATTGAT-3' & \\
\hline OLCA1SS1 & $a c t b$ & 5’-TGACGGAGCGTGGCTACTC-3’' & D89627 \\
\hline OLCA1AS1 & $a c t b$ & 5'-TCCTTGATGTCACGGACAATTT-3' & \\
\hline $18 \mathrm{SSS} 1$ & rn18s1 & 5'- CGTTCAGCCACACGAGATTG-3' & AB105163 \\
\hline 18SAS1 & rn18s1 & 5’-CCGGACATCTAAGGGCATCA -3' & \\
\hline
\end{tabular}


Table 1. (continued)

\begin{tabular}{llll}
\hline RPL7SS1 & rpl7 & 5'-CGCCAGATCTTCAACGGTGTAT-3' & DQ118296/Zhang and Hu (2007) \\
RPL7AS1 & rpl7 & 5'-AGGCTCAGCAATCCTCAGCAT-3' & \\
COL1SS1 & col1a1 & 5'-GAGAAATCTGGACTTGAA-3' & NM001122918 \\
COL1AS1 & col1a1 & 5'-GTACAGAGCAACCGAGTT-3' & \\
MT2SS1 & mmp15 & 5'-CTCAGTGACGATGGAGC-3' & AB072928 \\
MT2AS1 & mmp15 & 5'-GCGTGTTGATGATGGCGTAG-3' & \\
\hline
\end{tabular}


medaka EP4b human EP4 mouse EP4 zebrafish EP4

medaka EP4b

human EP4 mouse EP4 zebrafish EP4

medaka EP4b human EP4 mouse EP4 zebrafish EP4

medaka EP4b human EP4 mouse EP4 zebrafish EP4

medaka EP4b human EP4 mouse EP4 zebrafish EP4

medaka EP4b human EP4 mouse EP4 zebrafish EP4 medaka EP4b human EP4 mouse EP4 zebrafish EP4

medaka EP4b human EP4 mouse EP4 zebrafish EP4

medaka EP4b human EP4 mouse EP4 zebrafish EP4

medaka EP4b human EP4 mouse EP4 zebrafish EP4 $\triangle$

-.. MN M TQ VARP - . RA MS TPGVNSSA SLS P DRLNSP MS I PGVNASF SSTPERLNSP $\ldots . . . . .-$ ME $\bar{P} \ldots$. . TV TM2

ETT FYTLVCG LAVT DLLGTL ETTFYTLVCG LAVTDLLGTL ETTFYTLVCG LAVTDLLGTL $\bar{E} \bar{T} \bar{T} \bar{F} \bar{Y} \bar{T} \mathrm{~L} V \bar{C} \bar{G}$
TM1

PTVPVI MFIF GVVGNVI AI V VLRI S RKEQK

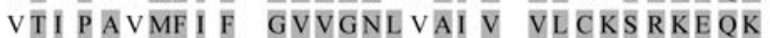
VT I P AVMF I F GVVGNLVAI V VLCKS RKEQK P TI P A I MF I F GVIIS NLI AI V VECKS RREK * TM3

AS PVTIAI Y MKGS WPGGDP L $\overline{\text { CQYSGFI LL }}$

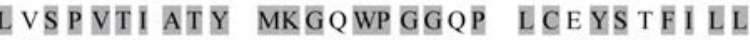
LVSTPTI ATY MKGQWP GDQA LCDYSTFI LL

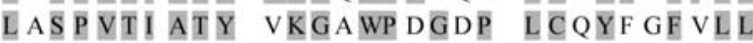
TM4

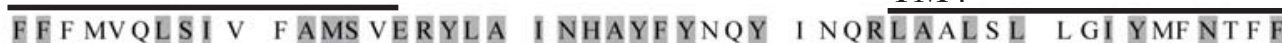

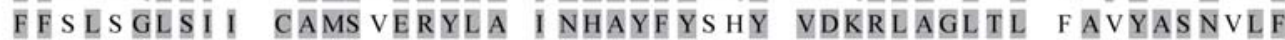

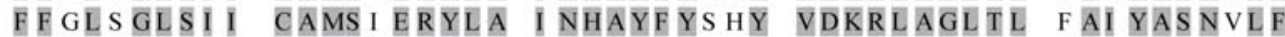
FE SEAGLSII CAMSI ERYI A I NHAYF YNDY VDKRLAGVTL LAI YASNI LF TM5

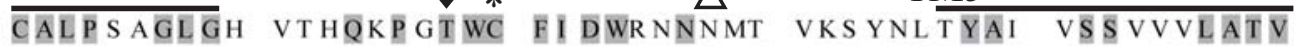

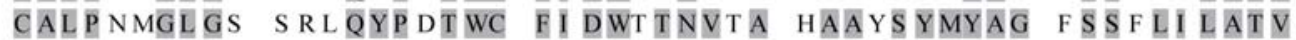
C A L P NMG L GR SER QYY $\bar{P} G \bar{T} \overline{W C}$ C AL P S V GF GE VKMQYP QT WC

FI DWT TNVTA YAAFSYMYAG F SS F LI LATV

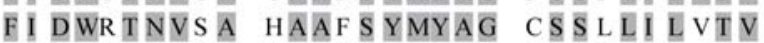

$\mathrm{I} C \mathrm{~N}$

I CNVMVCGAL I L MHKR F I RR TIS

TSETTDSRRL SE............................

CNVLVCGAL LRMHRQF MRR TISEGTEQHHA AAAAS VAS - - RGHPAASPA

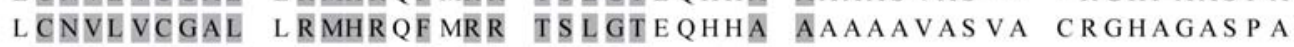

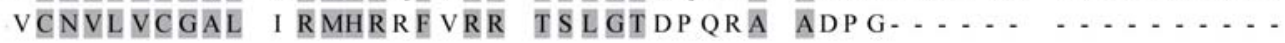

TM6

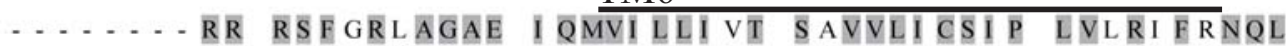

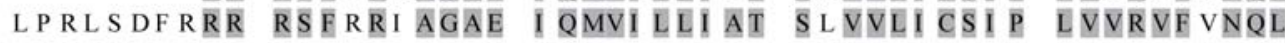

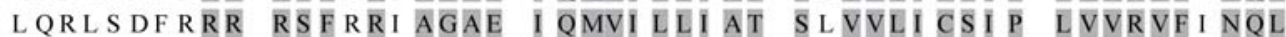

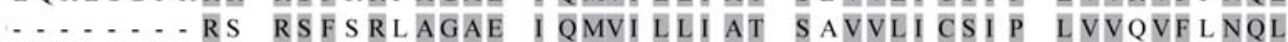
TM7

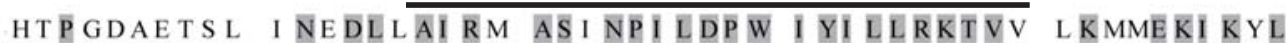

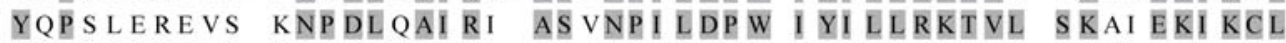
YQPNVVKDIS RNPDLQAI RI ASVNPI LDPW I YI LLRKT VL SKAI EKI KCL

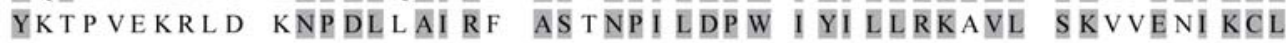

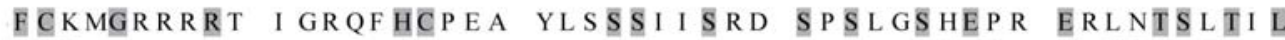

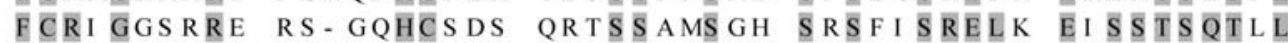

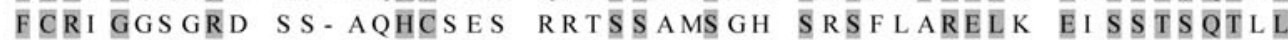

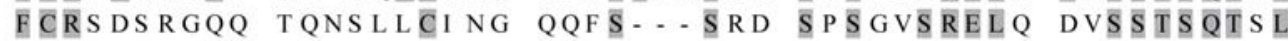

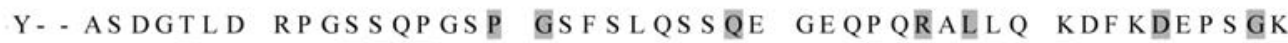

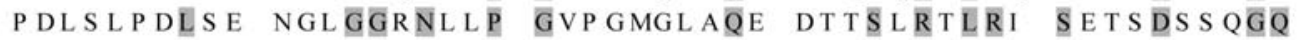

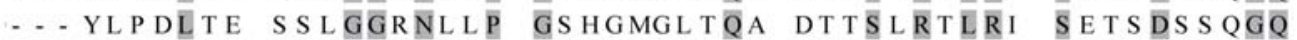

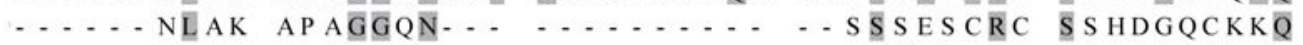

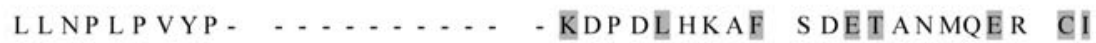

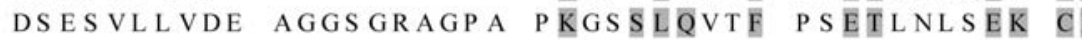

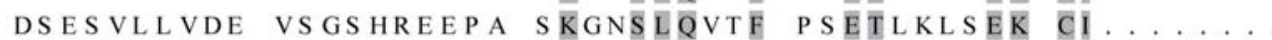
i...............

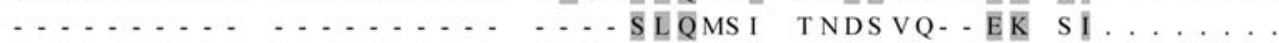

\section{Figure 1 Fujimori et al.}




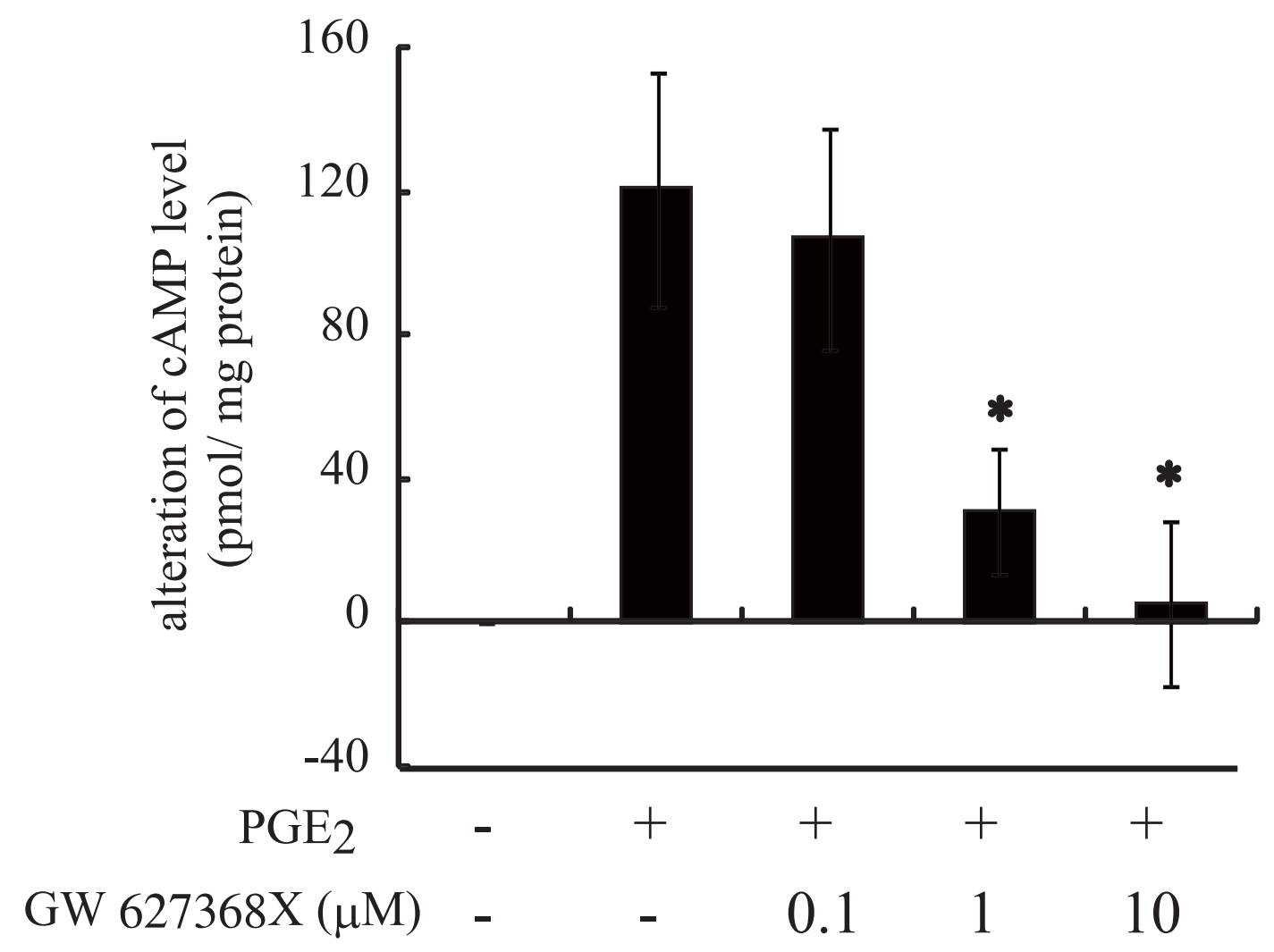

Figure 2 Fujimori et al. 
A

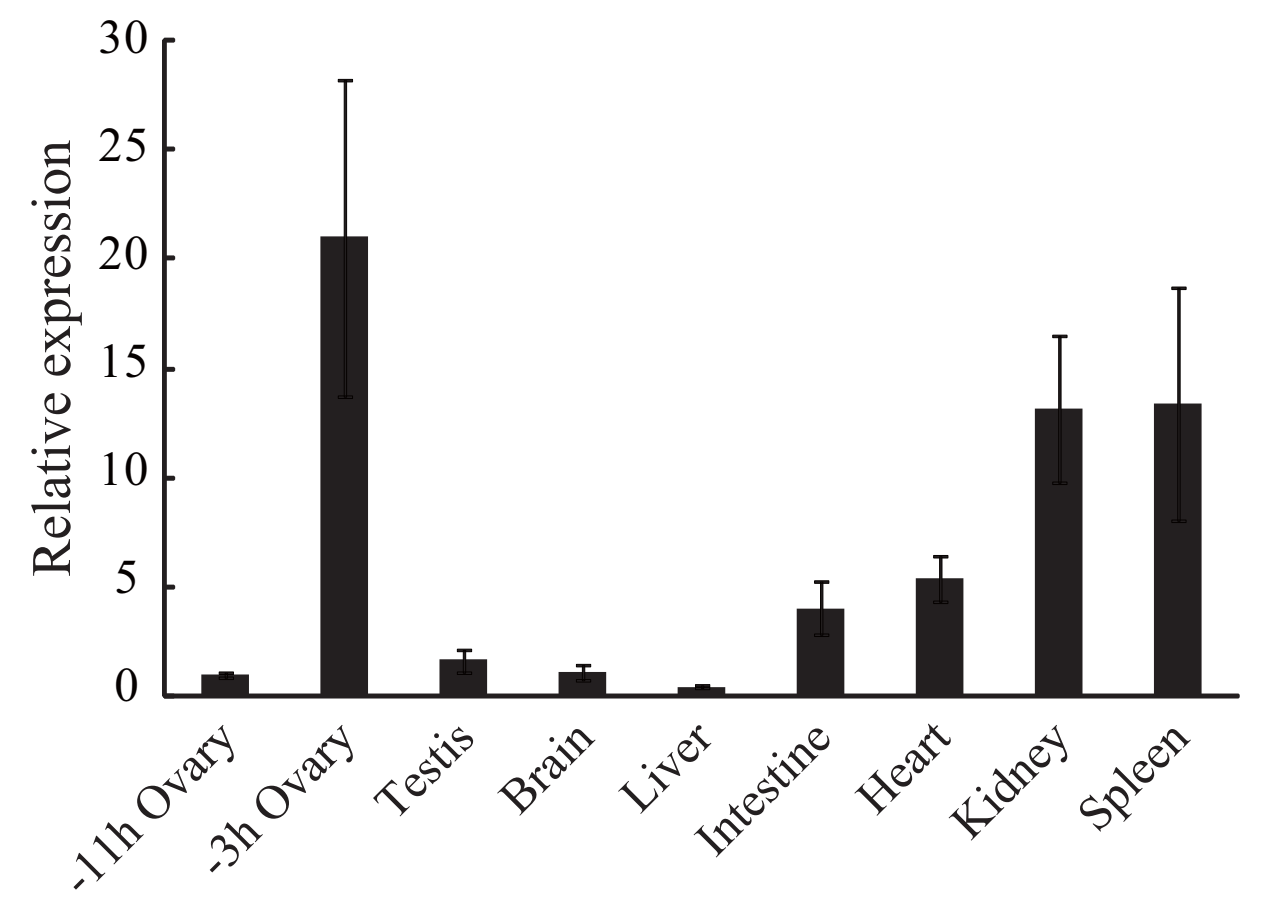

B

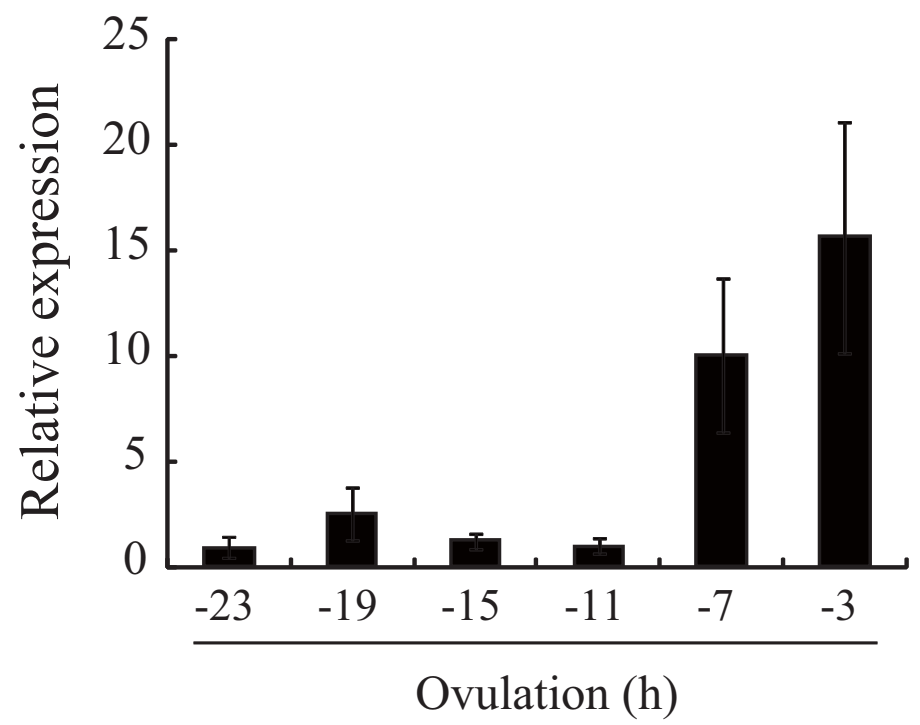

Figure 3 Fujimori et al. 
A

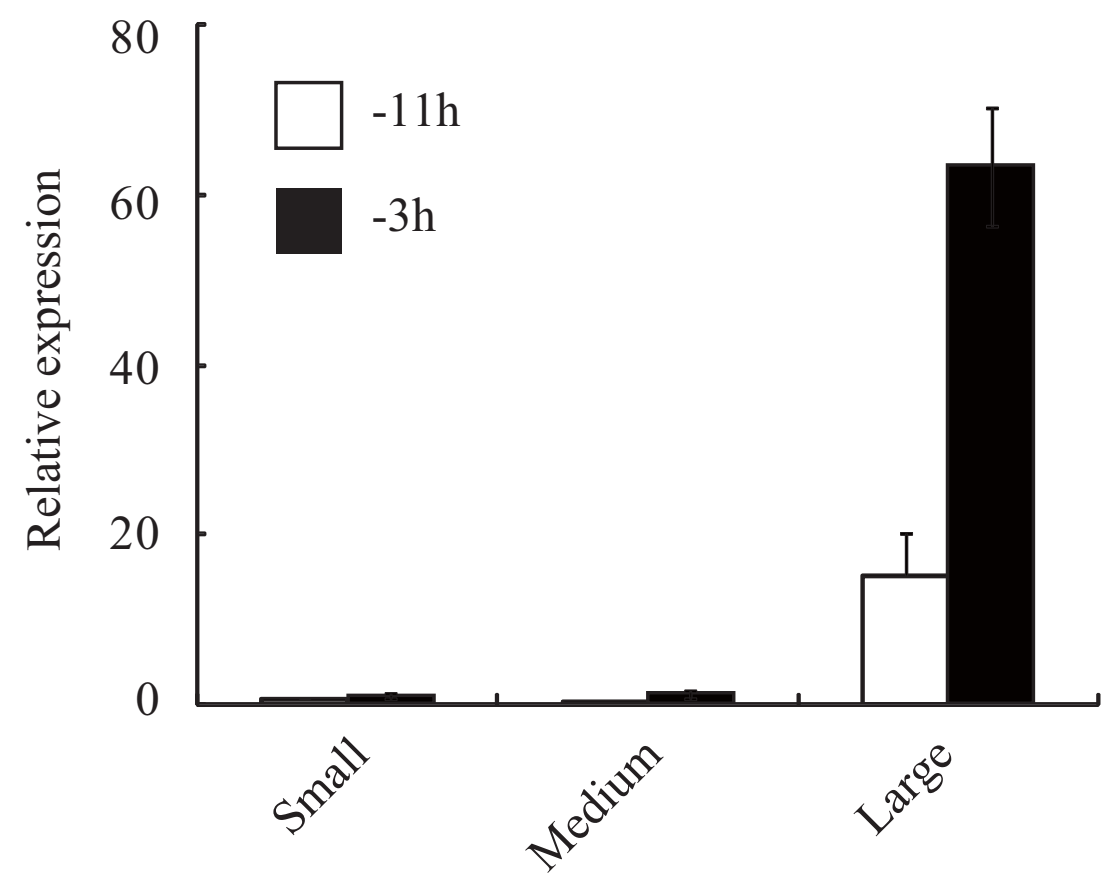

B

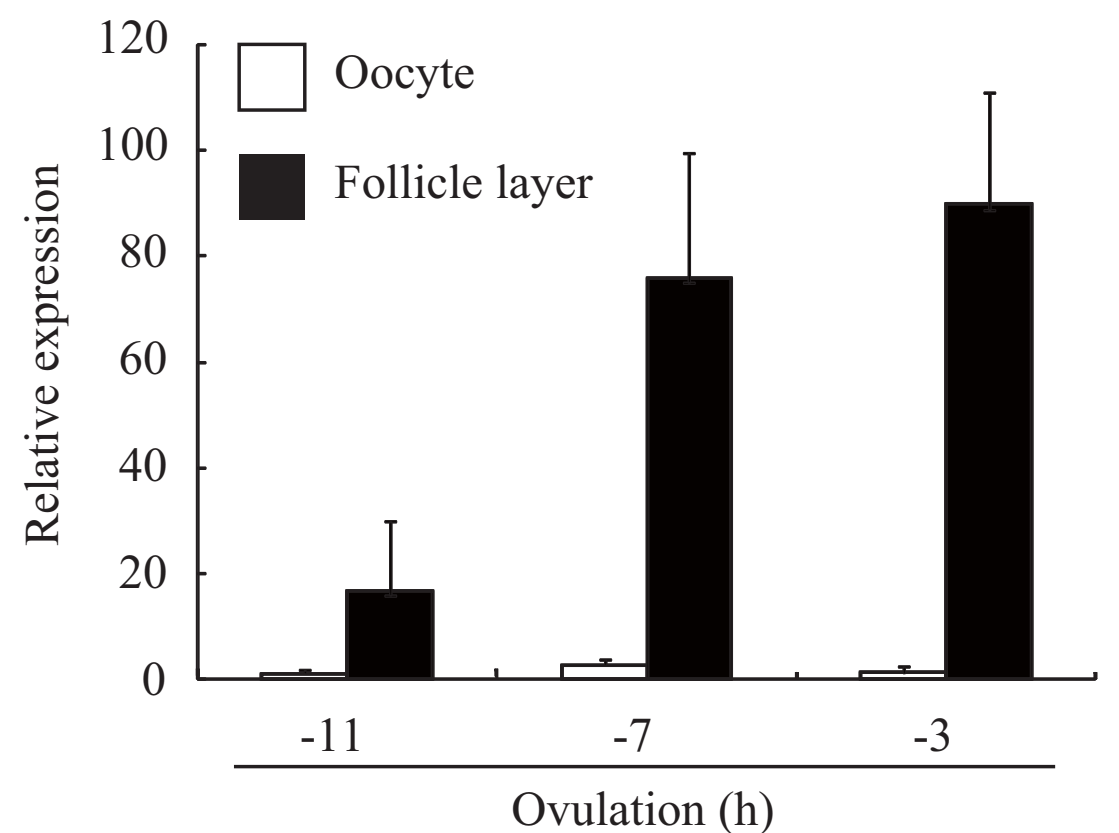

Figure 4 Fujimori et al. 
A

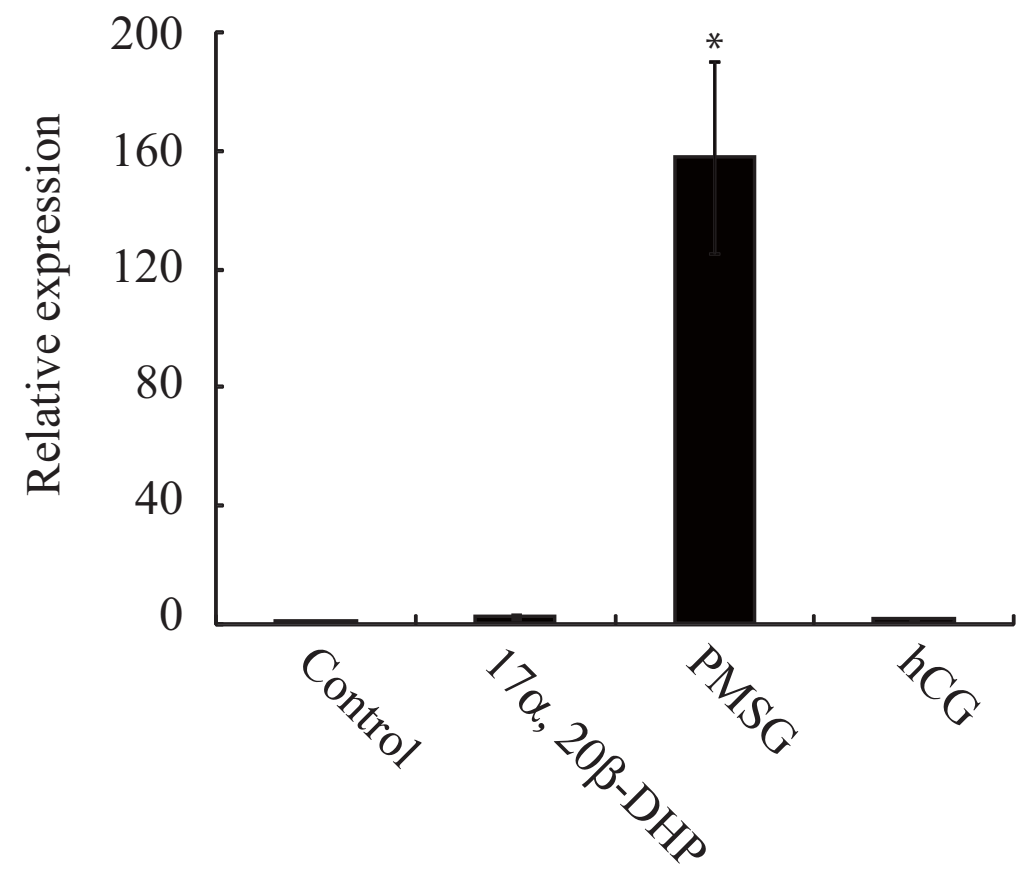

B

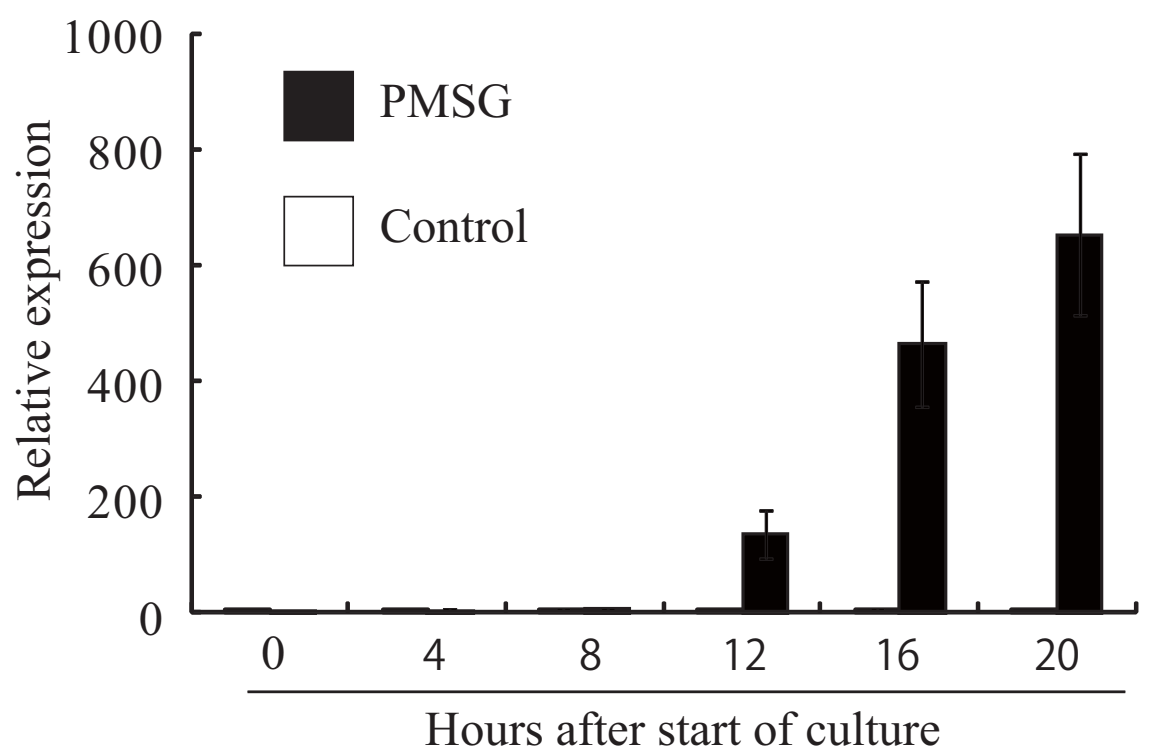

Figure 5 Fujimori et al. 


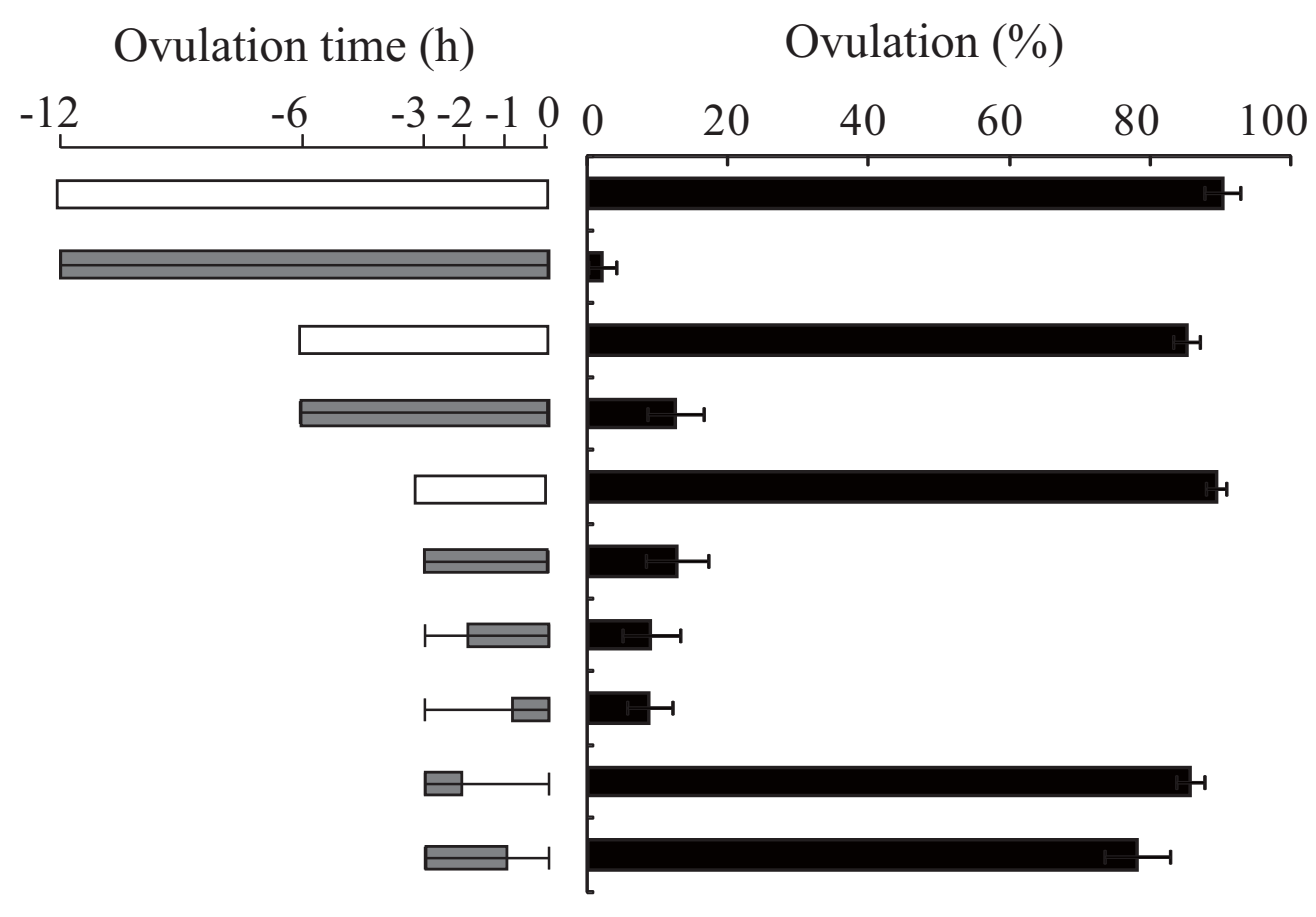

Figure 6 Fujimori et al. 